Mercator, Fortaleza, v. 16, e16028, 2017.

DOI: https://doi.org/10.4215/rm2017.e16028

ISSN: $1984-2201$

Copyright (c) 2002, Universidade Federal do Ceará

\title{
MANAGEMENT STRUCTURE OF THE SPANISH FISHING INDUSTRY
}

\author{
MARTINS, Cesar Augusto a*
}

(a) Phd in Geograph, Federal University of Rio Grande (FURG). http://lattes.cnpq.br/3468211709392384

\section{(*) CORRESPONDING AUTHOR}

Address: FURG/ICHI Av. Itália km 8 Campus Carreiros CEP 96203-900 Rio Grande (RS), Brasil. Tel (+55 53) 3233935123

E-mail: cavilamartins@yahoo.com.br

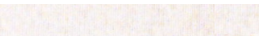

ABSTRACT

The study of the strategies and actions related to fishing industrialization enables the understanding of the tension between natural rhythms (stocks transformed into raw material) and social ones, represented by companies, the State and work. This paper problematizes the territorial changes and strategies of world economic groups in management centers in the Autonomous Community of Galicia in Spain. These corporate strategies place Spain as one of the largest producers of industrialized fishing in the world and have mitigated problems related to the access to raw material, labor conflicts, international competition and commercial chains that have their own trademarks. Companies invest in research, advertising, product diversification and the recognition of Galicia as a maritime power. The processes of territorial transformation are: the centralization of capital in a smaller number of companies; the externalization of phases of the productive process to Latin America and Africa; the separation of management centers and factories located in the old industrial areas; and the cincrease in mechanization that intensifies conflicts with the workers' organization of the sector. Keywords: Fishing industries; Companies; Territory

\section{ESTRUTURA EMPRESARIAL DA INDÚSTRIA PESQUEIRA ESPANHOLA}

\section{RESUMO/ RESUMEN}

O estudo das estratégias e ações da industrialização de pescado permite apreender as tensões entre ritmos naturais (estoques transformados em matérias-primas) e sociais, representados pelas empresas, pelo Estado e o trabalho. texto problematiza as transformações territoriais e as estratégias de grupos econômicos mundiais com centros de gestão na Comunidade Autônoma da Galícia na Espanha. Essas estratégias empresariais colocam a Espanha entre os maiores produtores mundiais de pescado industrializado e minimizam os problemas de acesso às matérias-primas, os conflitos trabalhistas, a concorrência internacional, inclusive em relação às redes comerciais com as marcas próprias. As empresas investem em pesquisas, em propaganda, na diversificação dos produtos e no reconhecimento da Galícia como potência marítima. Os processos de transformação territorial são: a centralização de capitais em um número menor de empresas; a externalização de fases do processo produtivo para a América Latina e África; a separação dos centros de gestão e das fábricas localizadas nas antigas áreas industriais; o aumento da mecanização que intensifica os conflitos com a organização dos trabalhadores do setor.
\end{abstract}

Palavras-chave: Indústria da pesca; Empresas; Território.

\section{ESTRUCTURA EMPRESARIAL DE LA INDUSTRIA PESQUERA ESPAÑOLA}

El estudio de las estrategias y acciones de la industrialización de pescado permite aprehender las tensiones entre ritmos naturales (stocks transformados en materias primas) y sociales, representados por las empresas, por el Estado y el trabajo. El texto problematiza las transformaciones territoriales y las estrategias de grupos económicos mundiales con centros de gestión en la Comunidad Autónoma de Galicia en España. Estas estrategias empresariales colocan a España entre los mayores productores mundiales de pescado industrializado y minimizan los problemas de acceso a las materias primas, los conflictos laborales, la competencia internacional, incluso en relación con las redes comerciales con las marcas propias. Las empresas invierten en investigaciones, en propaganda, en la diversificación de los productos y en el reconocimiento de Galicia como potencia marítima. Los procesos de transformación territorial son: la centralización de capitales en un número menor de empresas; la externalización de fases del proceso productivo para América Latina y África; la separación de los centros de gestión y de las fábricas ubicadas en las antiguas áreas industriales; el aumento de la mecanización que intensifica los conflictos con la organización de los trabajadores del sector.

Palabras clave: Industria pesquera; Empresas; Territorio. 


\section{INTRODUCTION}

The process of globalization of companies from different sectors with their economic, political and environmental consequences in the world of work and the emergence of oligopolies is a relatively debated issue. The strategies and actions of fishing industrialization, the focus of this study, allow us to understand the dynamics and tensions between natural rhythms like fish stocks transformed into raw and social materials, represented by the contradictory combination between distinct agents represented by the State, by companies and inter-state relationships with regulations for fishing, health, trade and work on vessels and in factories.

The dynamics and tensions between the agents are historically constituted from the plans and actions that are determined by the uses of the territory, defined in disputes by its uses in historyis decisive for the reproduction of the fishing sector. The premise considers the agreed and contradictory relationships between the territory and especially the companies and the State as hegemonic agents in reproducing the logic of accumulation in the multiple scales of the world system. The formulation advocates the distinction between the mode of production and its viability over time in different economic and social formations (LEFEBVRE, 1978; SANTOS, 1982). Therefore, the relationships between the various agents are constituted and historically constitute themselves from the plans and actions that determine and are determined in each economic and social formation considered by the uses of territory (SANTOS and SILVEIRA, 2001), thus being a social-spatial formation (SSF). ${ }^{1}$

The contents and forms produced are in a constant confrontational mutation, after all, science, technology and information are determined and determinant in the agents' ability to negotiate, propose and impose. Thus, the economic and social formations submitted to the general logic of the functioning of the world-system (WALLERSTEIN, 2009) and embedded in technical, scientific and informational innovations (ROSEMBERG, 2006; SANTOS, 1991) are produced and are a result of the use of the territories. Therefore, not only the territory, but the uses made by certain agents in a given social and economic formation, where the National State is central in the current historical period. Thus, the approach of this study allows the analysis of the territory as a field of tension between the powers of agents of unequal forces, constituted historically.

One of the challenges is to ally the historical approach of the SSF considered as the territory used in the technical-scientific informational period in which the geographic space itself could be called the "technical-scientific environment" (SANTOS, 1985, p.15) and that "the information will be considered as a "fundamental vector of the social process and the territories are, therefore, equipped to facilitate circulation" (SANTOS, 1996, p.191).

So, here, it is about the science, technique and information produced and used by certain agents. The reading of the fishing activity includes the analysis of how certain agents reproduce themselves territorially. The diversity of the activities of the companies that execute fish processing is summarized in the following typology: cooling, freezing, salting, smoking, canning, oil and flour manufacturing. In the text the central agents are Spanish companies that carry out the canning of fish. Canning makes the possibilities of the processed raw material flexible, which accounts for about $50 \%$ of the product's market price, allowing the diversification of condiments and the forms of presentation that increase the product's durability for up to five years due to the high perishability of fish. ${ }^{2}$

(1) The author benefited from the discussions of the Working Group "Socio-spatial formations: technical progress in urban and agrarian space" held at the XI Meeting of the National Association of Postgraduate and Research in Geography held in 2015 in Presidente Prudente (SP). The conceptual and methodological basis is: MARTINS, C.A.A.et al. Socio-spatial formations: technical progress in urban and agrarian space. Anpege Journal, v. 12 n. 18, 2016, pp 137-161

(2) For comparative purposes, it should be noted that, according to company interviews in Galicia and in Brazil, the workforce represents between 6 and $15 \%$ of the final price of a canned fish preserve. 
In order to simplify the article's presentation, these companies are considered economic firms/ groups, submitted to the same controlling power and as alocus of accumulation, possessing four central strategies: specialization, diversification, vertical integration and conglomeration (GONÇALVES, 2003).

The research is linked to innovation practices in order to achieve improvements in the volumes produced and productivity. The innovation aims at greater effectiveness in the use of raw materials (such as appropriate practices for fisheries, in the handling of fish and packaging materials and condiments), at work (the intensification of mechanization and new forms of arrangements during work phases) and the creation of new products and markets for certain social segments and / or areas (youth lines, hotels, restaurant chains, healthy food production for companies). Synthetically, innovation is considered to be the

introduction of new products or services or new techniques for production or operation (...) Innovations are also the new forms of marketing, sales, advertising, distribution, etc. - that result in lower costs and/ or higher turnovers (SANDRONI, 1994, p 173).

The research problematizes the territorial transformations and business strategies of companies with management centers in Spanish Galicia that transitioned from small enterprises industrializing pickled fish with diverse genesis in the nineteenth century to global economic groups in scale and scope. These strategies, it is reiterated, have placed Spain among the world's largest producers of industrialized fish.

The text articulates global data from the Fisheries and Aquaculture Information and Statistics Service and Fisheries statistics: commodities of the Food and Agriculture Organization (FAO)and the Spanish National Institute of Statistics (INE) with studies regarding Galician economic participation in Spanish and European arrangements with specialized publications, such as Promotion of production: the 25,000 largest Spanish companies, Alimarket Alimentación and Ardan - economic and competitiveness reports. The data may show small differences in relation to the totals and the years depending on the use of adjusted final data only, avoiding the preliminary data. Interviews held in Galicia in 2012 contribute to the information: at theNational Association of Manufacturers of Canned Fish and Seafood (ANFACO), the Museum of the Sea, in Vigo, with companies that produce canned fish, in the Massó Museum in Bueu, and the Sea Museum in Rianxo, and the Center of Interpretation of Preserves, on the island of Arousa. ${ }^{3}$

The text is divided into three parts: in the first there is a summary of the size of fish production and fish industrialization in Spain; the second deals with the origin of companies; and, finally, in the third, the transformations of the strategies of these companies in the last decades are discussed, consolidating certain uses of the territories in the world system.

\section{THE INDUSTRIALIZATION OF FISHING IN SPAIN}

In Spain, there is a centuries-long trajectory and worldwide relevance in fishing and canning production,

from its geographical, historical, economic and social characteristics. And while catches represent only a small proportion of GDP, the effects derived from it (diet, processing industry, shipbuilding, supplies) greatly increase its social interest (TAMAMES and RUEDA, 2008, p.208).

(3) ANFACO has its origins in the first decade of the twentieth century, in a context of labor disputes and negotiations for the purchase of fish. In the nineteenth century, $67.8 \%$ of the vessels, $47.9 \%$ of the fishing establishments, salting and conservation of fish and $71.8 \%$ of the workers in the sector in Spain were in Galicia (DIAZ DE RÁBAGO, 1885). 
Galicia is the location of $45 \%$ of Spanish canning companies, with $77 \%$ of workers and $85 \%$ of production and sectoral value. Spanish consumption is $44.7 \mathrm{~kg} /$ per capita/fishing year, $4.0 \mathrm{~kg} /$ per capita/ year of canned fish and $3 \mathrm{~kg} /$ per capita/ year of canned tuna. Thus, fish consumption in Spain is among the ten highest in the world.

A symbol of the Galician fishing industry's importance can be found in the lobby of Peinador Airport in Vigo, Galicia, the industrial and port center of the Spanish Northwest: the $300 \times 700$ centimeter panel painted by Rafael Alonso in 1982. In the panel, there is a pier with a fishing boat and fishermen and women with baskets of fish. Vigo, with a population of 296,000 (around 10\% of the Galician population), is noteworthy for the PSA-Peugeot Citroen factory, which was installed in 1958 as part of the conservative modernization project of the Franco regime (1936-1975), and the shipyards that produced fishing boats of different tonnage up to oil tankers. The capacity and complexity of the production of the shipyards produced vessels capable of navigating Galician waters and fishing in the polar waters of North or South America (SAN MIGUEL and GOMEZ BLANCO, 2009). The workers and shipyards were brought down by EU agreements, Asian naval poles, the world trade crises and fishing restrictions in certain periods, areas and species considered to be at some risk for their reproduction.

The marks of the restructuring are in industrial wastelands (friches) of shipyards near the central area of Vigo and in the memory of the sacked workers registered in the film Los lunes al sol (2002), directed by Fernando León de Aranoa, and in the closed fish factories occupied by the workers portrayed in 1989 in the documentary Doli doli doli, directed by Urqui Permui. The Galician Autonomous Community, marked by a rural hegemony with a power structure that drove out thousands of people to emigration, has in the panel at Vigo airport one of the marks of national and international territorial recognition: fishing and its products. Galicia, still bearing the marks of the unequal and combined relationship in the Spanish economic structure (BEIRAS, 1997), moves towards the specialization of the producers of the dairy and meat industries, energy production and the industrialization of paper, cellulose and textile articles, with the assertion of groups such as Zara (CARMONA BADIA and NADAL OLLER, 2012). However, Rafael Alonso's panel highlights the fishermen who pull in the nets and the women who soak their hands and bodies with the base of one of the world's riches: fish processed in industrial companies.

The strategies of the fishing industrialization companies involve the uncertainties of natural and social dynamics. Over time, the catch of different species was related, for example, to climatic oscillations that in the fifteenth century warmed the waters of the Northwest of present-day Spain and forced the migration of whales and cod to the North Atlantic, favoring the presence of sardines in Galician waters (FERREIRA PRIEGUE, 1998). In recent decades, there have been changes that indicate the displacement of some stocks, which force artisanal fishermen and companies to adapt their fishing strategies (FAO, 2012). With the oscillations of the natural dynamics, different social processes compromise the supply of raw material, such as overfishing above the reproduction limits of certain species or parts of the productive chains (ROBERTS, 2007).

In Galicia, fishing regulations involved conflict between ancestral arts and knowledge and the introduction of new fishing practices, when fishermen who used the xeito (carried out by boats with between two or six fishermen with driftnets combated the introduction of the xábega by immigrants from Catalonia. The xabega, introduced after 1760, used between 15 and 20 persons employed in the fishing process, which gave rise to the practice of trawling, leading to the so-called "trawler wars" (PEREIRA, 1998). Fishermen's fraternities have even prevented certain people from gaining access to fisheries and determine prices and labor regulations on safety and wages. The process culminated in resistance societies being formed in fishing and in a combative trade unionism of seamen in the first decades of the twentieth century (PEREIRA, 1992).

In relation to impacts of different scales, fisheries are subject to changes in water courses with dredging and channeling, to the implantation of fixed structures, such as ports, landfills, ditches, 
and support structures, as well as natural events such as storms, volcanism or tsunamis and human events, such as accidents like the Exxon Valdez, in Alaska, in 1989, the Prestigie, on the Galician coast in 2002, or British Petroleum, in the Gulf of Mexico in 2010.

The regulations among those operating in the sector, such as fishermen, traders and processors of fishery products, originally became state-owned within the territories of each SSF (since antiquity, as in the Chinese, Egyptian and Roman Empires), transitioning to interstate norms from the sixteenth-century doctrinal debates on the use of the seas and especially after the creation of the United Nations and the transfer of part of the scientific and technological advances of wars to the fishing activities.

One of the results for fisheries and the industrialization of fish was the development of state policies to build business bases to undertake the capture and processing of fish as one of the foundations forformatting urban-industrial society in different SSFs, in which the processes are distinct in given periods (with the use of installed productive capacities or certain agents). In the fishing industry, there are the examples of the Mitsui and Mitsubishi groups in Japan, after World War II (LAGO, 1982), and Pescanova, in Francoist Spain (MEGUEZ MACHO, 2011); groups that, by adopting the verticalization and horizontalization of production, compete for raw materials and markets around the world.

In Brazil, the actions of the Superintendence of Fishery Development, Decree 221/67 and the Fisheries Investment Fund (FISET / Pesca) in the 1980s collaborated to make the Quaker Oats factory, in São Gonçalo, state of Rio do Janeiro, the world's largest fish cannery at the beginning of the twenty-first century, processing one million cans per day (MARTINS, 2006). ${ }^{4}$ For comparison purposes, at the beginning of the twentieth century, the Curbera factory in Galicia produced around 9,000 cans / day and Albo de Vigo increased production from 2,700 cans / day in the late nineteenth century to 100,000 cans / day in 1916 and 300,000 cans / day in 1930.

In Spain, the increase in the supply of raw material to factories had been taking place since the nineteenth century, such as withtheintroduction of thexábega and accelerated by the technological contributions to increase catches. The productivity of fishermen increased from 1.16 tons / year between 1883 and 1892 to 2.33 tons / year between 1930 and 1934 and that of vessels from 4.56 to 8.80 tons / year in the same period (GIRALDEZ RIVERO, 1991).

Despite measures aimed at reducing or even preventing the capture of different species and competition with other meats produced in the logic of agribusiness; at the beginning of the twenty-first century, there were machines capable of preparing 400 cans of fish per minute. Some Galician companies process up to four million cans per day in their factories, combining production based on the seasonality of species and tend to concentrate production on tuna, which increases the possibilities of mechanization while there is a tendency to maintain mainly female manual labor (VELEDA DA SILVA and MARTINS, 2016). ${ }^{5}$

(4) In 1973, Quaker acquired the Coqueiro factory, founded in 1937.In 2002, Quaker was bought by the Pepsico group. In 2011, the Camil group acquired the Coqueiro plant in Itajaí, in Santa Catarina, and FEMEPE, located in Navegantes in the same state, re-dimensioning the Brazilian canned fish market in competition with Gomes da Costa (factory in Itajaí) and Robinson Crusoe (Leal Santos factory in Rio Grande in the southern state of Rio Grande do Sul), controlled respectively by the Spanish groups Calvo and Jealsa based in Galicia..

(5) On the subject in Brazil, see: VELEDA DA SILVA, SM and SPOLLE, M. Female labor in fish canneries: the permanence of labor exploitation. Scripta Nova, v. XVIII, No. 464, January 10, 2014. Available at http://www.ub.edu/geocrit/sn/sn-464.htm. Accessed on 04/10/2014. 
MARTINS, C. A.

\section{THE GENESIS OF THE COMPANIES INDUSTRIALIZING CANNED FISH AND THE PRODUCTION OF FISH IN SPAIN}

The literature establishes the origin of the fish canning companies in Galicia on the presence of immigrants from Catalonia and, to a lesser extent, from Brittany. In the first half of the nineteenth century, especially, Catalan immigrants introduced vessels and techniques that increased the scale of catches, which produced surpluses of processed fish in the factories. This generated conflicts between the Galician fishermen who defended the simple techniques of capture and the new ship owners. In the factories, accelerated work rhythms were imposed to process larger volumes of fish and the women's salaries were reduced.

The presence of immigrants to implement the fishing industry also occurred in the late nineteenth century in southern Brazil and in Cantábria with "Mediterranean capitals" (ORTEGA VALCARCEL, 1986). In Galicia, the Catalans were called "developers" (SANTOS CASTROVIEJO, 1998, p.95), and the Areal neighborhood in Vigo was considered the "Catalan neighborhood" (BEIRAS, 1997: 143).

Carmona Badia (2011) analyzed the history of 29 family businesses that worked and / or work in the canning industry. Based on this analysis of the hegemonic agents of the sector in the nineteenth century it is possible to infer that there are: (a) traders of different origins and commodities; (b) immigrants with capital produced in the Americas; (c) successive marriages between members of the families; (d) diversification of investments in banks, shipyards and real estate development; (e) the presence in municipal executives of members of the Massó, Garavilla and Jesus Alonso Fernandes (Jealsa Riaxeira) families who control important canneries.

Of particular note is the amalgamation of their trajectories with State policies: guaranteeing quotas for the acquisition of fish, cans and oils during part of the Franco regime; active participation in the debates on research of fish stocks and innovations by universities and other institutions; the organization of industrial estates, displacing factories from their original locations; discussions on catch quotas and imports into the European Union at international forums; obtaining public funds such as the fund of the Galego Institute for Economic Promotion (IGAPE) and the European Fisheries Fund (EFF). ${ }^{6}$

In a global scenario of small oscillations, with increased technical conditions for the conservation of fresh and frozen fish and competition from other foods, especially other meats and grain products, the consumption of preserves has resumed growth and is controlled by firms and economic groups trending towards oligopolistic markets (Table 1).

Table 1 - Global Fish Consumption (in \%)

\begin{tabular}{c|c|c|c|c|c|c}
$\begin{array}{c}\text { FORMS OF } \\
\text { CONSUMPTION }\end{array}$ & $\mathbf{1 9 4 8}$ & $\mathbf{1 9 6 8}$ & $\mathbf{1 9 7 8}$ & $\mathbf{1 9 9 0}$ & $\mathbf{2 0 0 0}$ & $\mathbf{2 0 0 8}$ \\
\hline Human consumption & 87.0 & 62.0 & 69.6 & 72.2 & 76.3 & 84.2 \\
\hline Fresh & 50.0 & 28.0 & 20.9 & 23.0 & 37.6 & 39.4 \\
\hline Frozen & 12.0 & 13.0 & 20.2 & 24.2 & 20.4 & 24.1 \\
\hline Dried / smoked & 25.0 & 13.0 & 14.4 & 11.9 & 8.7 & 8.6 \\
\hline Canned & 7.0 & 8.0 & 14.1 & 13.1 & 9.6 & 12.1 \\
\hline Other purposes & 13.0 & 38.0 & 30.4 & 27.8 & 23.7 & 15.8
\end{tabular}

Source: FAO. Fishery statistics - products. Produced by: César Martins

(6) In 2013, ANFACO, together with the University of Vigo and the Xunta of Galicia, announced the project for the construction of a unit for the production of trout in captivity in Santa Bárbara, Peru. The forecast is a contribution of 155 of the 208 thousand euros of the total investment by the Galician government. 
In the process of world-wide competition over certain fish stocks and trade openings that allow a wide circulation of goods, the sector is controlled by some groups in certain SSFs. In Japan, by Hagoromo Foods \& Maruha Corporation; in the United States of America, by the Starkistcompanies (Heinz group), Chicken of the Sea (Tri-Union Seafoods group) and Bumble Bee (ConAgra Foods group); in Italy, by Bolton Alimentari and General Conserve; in France, by the Petit Navire, of the Thai group Thaï Union Frozen Group (TUF), and Salpiquet, of the Bolton group. In Spain, Calvo, Frinsa, Garavilla and Jealsa Rianxeira lead the market. Among the strategies for the movement of goods are the acquisition and construction of factories in different countries, such as Calvo, in Brazil and in El Salvador, and Jealsa, also in Brazil, Chile and Guatemala. Another strategy is the flexibility of production, such as that of MW Brands, a subsidiary of MW Brands Holdings SAS, acquired by TUF in 2010, which from its headquarters in Paris controls the work of around five thousand employees who produce traditional brands such as the Italian "Mareblue" and the British "John West" in factories in France, Portugal, Ghana or Seychelles.

In Spain, since the 1960s, there have been at least two orientations that assert the country as a major producer and consumer of fish. The first was the 1961 Fleet Renewal Act, which allocated resources to the construction of vessels to operate in the Atlantic Ocean: (a) to the Northwest and North, catching cod, squid, horse mackerel and monkfish; (b) to the South and Southwest, of hake, corvina and shrimp.

In a global context of low growth of marine catches in recent decades (from 78.2 million tons in 1990 to 79.9 in 2009 and 81.5 in 2014), Spain also reduced its fisheries, but remained among the largest producers of fish of extractive origin (Table 2).

Table 2 - Ten main global producers of fish caught, Spain and Brazil (in thousand tons)

\begin{tabular}{r|c|c|c|c} 
COUNTRY $($ position in 2009) & $\mathbf{1 9 8 9}$ & $\mathbf{2 0 0 0}$ & $\mathbf{2 0 0 5}$ & $\mathbf{2 0 0 9}$ \\
\hline $\mathbf{1 .} \quad$ China & 6,362 & 14,648 & 14,588 & 14,919 \\
\hline 2. Peru & 6,815 & 10,657 & 9,388 & 6,914 \\
\hline 3. $\quad$ Indonesia & 1,992 & 4,080 & 4,695 & 5,099 \\
\hline 4. $\quad$ United States & 5,475 & 4,717 & 4,892 & 4,222 \\
\hline 5. India & 2,246 & 3,666 & 3,691 & 4,053 \\
\hline 6. Japan & 10,973 & 5,072 & 4,312 & 3,847 \\
\hline 7. $\quad$ Russia & $10,290(1)$ & 3,973 & 3,197 & 3,826 \\
\hline 8. Chile & 6,815 & 4,300 & 4,328 & 3,453 \\
\hline 10. Myanmar & $\ldots$ & 1,093 & 1,732 & 2,766 \\
\hline 21. Spain & $\ldots$ & 1,893 & 2,269 & 2,602 \\
\hline 23. Brazil & 1,339 & 1,057 & 853 & 904 \\
\hline
\end{tabular}

(1) Data concerning the defunct Union of Soviet Socialist Republics

Source: FAO. Fisheries and Aquaculture Information and Statistics Service.

From the point of view of catches, the transfer of some of the equipment developed for the maritime conflicts of the world wars (communication, detection, atmospheric forecasting and increased displacement equipment) allowed the increased efficiency of the fleets. With the assumption that the oceans had almost inexhaustible resources, the volumes of catches of both traditional and newly discovered species increased exponentially. In Spain, between the 1950s and 1970s, this process led to a reduction in the number of vessels and a rise in their average capacities and catches. With the oil crisis and signs of the depletion of several species, from an economic and environmental point of view the fleet became idle in the 1990s.

The development of the fishing policies of the future European Union, based on the capacity of stocks and establishing quotas for each national fleet. With the adjustments of Law 33/1980, which

(7) Regarding the Jealsa company actions in Guatemala, see: MELENRELAS, P. The tuna enclave of Rianxeira in Guatemala, 2010: myths and realities. Guatemala: Universidad de San Carlos de Guatemala, 2010 (available at http: dig.usac.edu.gt). The dynamics of the companies in the canned fishery sector is carried out with the reports of the Canned Food Industry Market Research Reports available at http://www.reportlinker.com. 
created the Fund for the Regulation and Organization of the Market of Fishing Products and Fishing and MaritimeProducts (FROM), the conditions were prepared for the adoption of control and quota measures within the scope of the CommonFisheries Policy (CFP) in 1983, for the creation of the FinancialInstrument for FisheriesGuidance (FIFG) in 1992 and the European FisheriesFund (EFF) in 2007. Adjustments to the catch capacity and fishing performance of the Spanish fleet over the last six decades are recorded in the reduction in the number of vessels and fisheries: 46,959 vessels with 845,000 tons in 1959; 16,749 vessels and 1,355 million tons in 1974; 10,505 vessels and 968 thousand tons in 2011. The reduction in the fleet was accompanied by an increase in average vessel capacity (8.30 tons in 1956, 44.46 tons in 1974, 37.97 tons in 2011), with an increase in the average catch per vessel: 18 tons in 1956 to 89.44 in 1974 and 92.20 in $2011 .{ }^{8}$

The second orientation was from the point of view of industrial fish processing. In the 1960s, the Spanish state took measures that adjusted the perspective of fiscal control and the ostensive use of certain resources by temporarily formed factories and signaled the reorganization of the sector based on companies with greater processing capacity. In 1965, the Ministry of Industry established that the minimum capacity of a fish canning factory should be 400 tons of annual production. The structure of the Spanish fishing industrial plant is shown in Table 3 and indicates the combination of selectivity in the fleet and a reduction in the number of factories, an increase in productivity per unit with a small reduction in the number of workers and an increase in mean production, the result of initiatives to mechanize some phases of the productive process, such as fish cleaning.

Table 3 - Spain: number of fish and canned fish factories, number of workers, average production ( $\mathrm{t}$ ) and average number of workers per establishment in selected years

\begin{tabular}{c|c|c|c|c} 
YEAR & Number of factories & Average Production & Number of employees & Average number of workers \\
\hline $\mathbf{1 9 5 9}$ & 791 & 62.55 & 18,659 & 223.58 \\
\hline $\mathbf{1 9 7 1}$ & 498 & 210 & 19,299 & 38.75 \\
\hline $\mathbf{1 9 7 7}$ & 421 & 277.8 & 18,492 & 43.92 \\
\hline $\mathbf{2 0 1 1}(\mathbf{1})$ & 147 & $2,445.2$ & 15,375 & 104.59
\end{tabular}

Sources: National Institute of Statistics. Industrial statistics: industries derived from fishing. (1) Industria Conserveira Magazine, $n^{\circ}$ 92, 2012. Organization: César Martins

In this way, the elements presented on global and Spanish dynamics of fishing activity and in relation to the industrialization of fish, allow the analysis of the business structure and the strategies of the canning companies in the context of oligopolistic disputes that include debates and decisions in the European Parliament on fishing quotas and imports of fishery products between the members of the European bloc and of the bloc with other countries or blocs. ${ }^{9}$

(8) The data on the fleet are from: MINISTRY OF AGRICULTURE, FOOD AND ENVIRONMENT. Fishery statistics, 2012; LARREA, S. Sea fishing. El Campo, n. 126, 1992, 75. The catch data were made compatible by: FAO. Fisheries and aquaculture statistics: capture, product and fleet. Rome, 2012.

(9) Spain and ANFACO play an active role in shaping fishing policy in the European Union. In the interviews with ANFACO and the Spanish companies, the subject was treated with reservation by the interviewees who showed discomfort with the increase of import quotas of Asian countries and with the acquisition of traditional European companies by economic groups of other nationalities. Among the documents of the European Parliament on the subject, see the registers: "In view of the generous tariff policy observed by the Community on imports of canned sardines from third countries; also considering that imports originating in Morocco as a consequence of the terms of the Association Agreement will enter the Community market as from 1999 under full liberalization (...) In the last 10 years, 26 of the 52 sardine canning companies operating in Portugal in 1986 were closed. During the same period (1986-1996), exports of canned sardines from peninsular Spain - in practice in Galicia - decreased by almost $40 \%$ and the canning factories in the Canary Islands - the main exporter of this product in Spain - decreased from 7,500 tonnes to 134 tonnes "(http://www.europarl.europa.eu/sides/getDoc.do?pubRef=-//EP//TEXT+REPORT+A4-1998-0137+0+DOC+XML+V0// PT. Accessed on 12/01/2012). 


\section{THE STRUCTURE AND STRATEGIES OF SPANISH FISH CANNING COMPANIES}

The existence of establishments that carry out various activities limits the equivalence of data on production capacities, production by segment and workers' registers worldwide. However, the production of canned fish increased from 4.74 million tons in 1976 to 7.55 million tons in 2009 , with tuna production standing out at $10.97 \%$ in the former year and rising to $68.21 \%$ in the latter. Japan is the world's largest producer (36.41\% of production in 1976 and $15.11 \%$ in 2009), despite the rise of new producers, especially Thailand, China and Myanmar, responsible for $30.6 \%$ of world production in 2009 and the maintenance in absolute terms of historically relevant producers such as the United States of America, Germany and France. The importance of the work of and in Spanish companies placed Spain among the ten largest producers of canned fish in the world, with special attention to the production of canned tuna: in 1976 the country accounted for $2.15 \%$ of canned fish (6.15\% of tuna) and, in 2009 , for $4.50 \%$ of canned fish ( $13.77 \%$ of tuna).

In Spain, according to Industrial company survey of the INE, the fishery sector (CNAE 10.2) went from 572 companies with 19,737 workers in 2008 to 552 companies and 18,581 workers in 2010. For the purpose of adjusting the research, the companies analyzed are fish canneries located in Galicia, especially those related to ANFACO, that is, the most relevant in the sector in Spain: of the 147 Spanish companies, 65 are in Galicia. They account for about $85 \%$ of the volume and production value and employ $77.72 \%$ of the workers in the sector. ${ }^{10}$

One of the strategies adopted for the maintenance and extended reproduction of the companies is still the use of territory, from the application of mechanisms to the appropriation of part of the fishermen's work. They took the fish from the water, which had its durability increased when processed. This allowed the construction of a large consumer market in the country. It should be noted that women were still responsible for this processing, enduring poor working conditions, seasonality and low wages (ABELEDO, 2010; VELEDA DA SILVA and MARTINS, 2016). On this basis, companies have adopted strategies that can be synthesized in maintaining historical cooperation between companies to ensure:

(a) the supply of cans in the period of the Spanish Civil War, in which there were supply problems, and in the Franco period, the period of economic and political blockades. The bottleneck in relation to the availability of cans for the industry was overcome with the presence of the Carnaud company in Spain (currently Crown Holding, the world's largest producer of food packaging);

(b) in the use of production residues for the manufacture of fish meal with the company Auxiliar Conservera- (AUCOSA), which emerged in 1959;

(c) the purchase of fish at lower prices with the structuring of the Manufacturers of Preserved Foods (FACORE) in 1965;

(d) the scale-up in the storage of fish caught worldwide with the structuring of the firm Frigoríficos Puebla (FRIPUSA) in 1971;

(e) the production of innovations: control over factory work in the last quarter of the nineteenth century based on Taylorist scientific management; cultivation of some species capable of industrial processing from the 1940s; equipment patents; differentiation of products regarding packaging (elimination of the stamp on the tin, transition from tin cans to aluminum and plasticsand from easy-open to pull seal $\left.{ }^{11}\right)$.Private or state-owned enterprises advertisinghealthy

(10) Revista Industria Conserveira, n. 94, January-February 2012.

(11) Easy-openis a packaging or lid with a ring pull to make it easier to open.Pull sealare a series of packaging tops made of flexible synthetic material that is easy to open and close at the different times that it is used / consumed. 
food (products low in sodium, light and diet) The move towardsenvironmental certification of the raw material harvested or cultivated with international seals regarding thehealthfulness of the processes in the fishing and the factories. ${ }^{12}$

One of the companies difficulties is reconciling the maintenance of activities and the decrease of the rates of inactivity due to seasonality and environmental commitments to the sustainability of its raw materials. There are multiple territorial strategies used by companies to overcome the difficulties in obtaining raw materials. These include the use of refrigerated warehouses at strategic points throughout the world, increasing the autonomous capacity of fishing vessels that can travel for thousands of kilometers and the purchase of fish in several countries with the increasinglyintensive use of reefer containers. In the research carried out in the fish factories the following industrially processed species were identified:agujas, almejas, atuns, bacalao, berberechos, caballas, calamares, mejillones, navajas, pulpo, sardinas, and zamburinas..$^{13}$ Thus, the appropriation of the rhythm of reproduction of different species occurs with the adoption of productive calendars differentiated in relation to the seasonality of each resource that can be obtained on a global scale. The processing schedule varies from two months (agujas, almejas, navajas and zamburinas) toup to twelve months (tuna).Aspreviously shown, there is a growing worldwide trend of industrialized canned tuna. "Tuna" is the popular name of 48 species of the Scombrida family and four of them are among the 70 species of fish identified by the FAO as the most fished: Skipjak Tuna (Katsuwonus Pelamis), Yellowfin Tuna (Thunnus Bacares), Bigeye Tuna (Thunnus Obesus), andAlbacora (Thunnus Alalunga).

In the Codex Alimentarius the following "tuna" are recognized for canning: Thunnus alalunga, thunnus albacares, thunnus atlanticus, thunnus obesus, thunnus maccoyii, thunnus thynnus, thunnus tonggol, euthynnus alletteratus, euthynnus lineatus, katsuwonus pelanis (or euthynnus pelamis), sarda chiliensis, sarda orientalis and sarda sarda. The regulatory frameworks for fishing quotas, the capacity to reproduce stocks and the possibilities of fishing in different areas with the technical capacities of vessels, as well as world trade with the safety of containers, are limits and possibilities for companies with the maintenance and transformation of the production base. Maintenance is related to the historical exploitation of the diversity of species that guarantee the scope of the industries. The transformation involves the increase of the scale of the participation of canned tuna in the companies' portfolios (Table 4).

Table 4- Spain: main species used in canning(order of importance in 1961)

\begin{tabular}{c|c|c|c|c}
\multirow{2}{*}{ Species } & \multicolumn{2}{|c}{1961 (1) } & \multicolumn{2}{c}{ 2011 (2) } \\
\cline { 2 - 5 } & \% of tons & \% of value & \% of tons & \% of value \\
\hline Anchoa & 18.37 & 9.67 & 3.73 & 7.66 \\
\hline Bonito, albacora, sarda & 15.16 & 38.72 & 3.73 & 6.39 \\
\hline Cockle & 6.82 & 3.40 & 1.46 & 4.51 \\
\hline Mackerel, verdel, sarda & 5.50 & 5.12 & 4.24 & 7.40 \\
\hline Mejillone & 5.08 & 2.09 & 3.99 & 48.42 \\
\hline Tuna, perch, bighorn & 4.14 & 6.89 & 63.81 & $\ldots$ \\
\hline Chicharro, mackerel & 3.46 & 4.08 & $\ldots$ & $\ldots$ \\
\hline Chopa, dorada, lisa & 2.58 & 1.04 & 7.84 & 6.39 \\
\hline Sardine & 2.20 & 20.18 & 88.8 & 87.7 \\
\hline Subtotal & 63.61 & 91.19 & 11.2 & 12.3 \\
\hline Other species & 36.69 & 8.81 & 100 & 100
\end{tabular}

Sources: (1) National Institute of Statistics. Industrial statistics: industries derived from fishing. (2) Indústria Conservera, January-February 2012, p. 25-26. Fieldwork in Galicia in 2012. Organization: César Martins.

(12) The research identified innovations linked to the needs arising from the isolation of the Franco period, with the diversification of processes and products. In the period of the field activities, the company Pescamar, carried out experiments to produce a can of fish with spaghetti type pasta and similar.

(13) The names of the species are in Spanish to keep the information obtained in the factories and used in the finished product for commercialization. (needles, clams, tuna, cod, cockles, mackerel, squid, mussels, razor, octopus, sardines, and zamburinas) 
For comparison purposes, it should be noted that the average price of canned processed fish in Spain in 2011 was $€ 3.91$ / kilo, tuna was $€ 8.30$ / kilo and species considered specialties, such berberechos, navajas and almejas, were $€ 17.14$, $€ 15.33$ and $€ 9.27$ respectively. ${ }^{14}$

The increase in the use of some tuna is linked to the high homogeneity of the individuals that optimizes the capture and storage processes in the ships. There are also agreements for the operation of Spanish fleets in the territorial waters of other countries that have a limited capacity to exploit some stocks and in international waters to catch fish with less compromised reproductive capacities and that can be certified by environmental organizations. In factories there is a tendency to increase the use of equipment at all processing stages, reducing the number of workers and breaking the long tradition of handling fish.

Thus, between 1990 and 2009, Spain remained an active participant in the world fish trade. The country was the third largest importer of fish with around $6 \%$ of the global total, while exports rose from $2.03 \%$ in 1990 to $3.27 \%$ of the total volume.

Another strategy for companies in relation to canned tuna is the differentiation between products, in addition to the size of the packaging and the use of condiments: there are product lines that identify the canned species, the place of capture and the fishing equipment with higher prices and other low-priced, unspecified mass-produced production lines that use the brands of large retail chains. The theme of the manufacture of canning by traditional companies that produce their own brands and for others involves secrecy, since there are about 4,100 ways to present preserves in Spain, 30\% of which are called "Distributor Marks" (DM) representing $73 \%$ of the volume and $64 \%$ of the sales value (ALCUBILLA, 2012). ${ }^{15}$

Tuna without identification on the packaging is a strategy for companies to compete with cheaper foods and brands from other countries exporting to Europe with facilities offered under agreements within the European Union. Jointly, the inclusion on the packaging of the fishing equipment used and the fishing area is maintained, seeking the fidelity of a certain strata of consumers. In Spain, the strategy is adopted, for example, by companies in the north of the country with the tuna identified as "bonito del norte" (thunnus alalunga). Bonito del norte, known as "ventresca", is caught with live rod and bait and marketed in glass containers that show the fish pieces soaked only in olive oil.

In the logic of oligopolized competition in Spain, the European Union and other continents, companies bet on the closure of the old factories with the separation of production from the management center (in some cases with headquarters transferred to Madrid with the advantages of Barajas, the main Spanish airport, and the land transport network with European funding) and the shift of production to industrial estates with alliances with real estate capital for investments in the old land in prime locations along the banks of watercourses.

In companies that hegemonically have family control, different levels of professionalization of executive positions are under way. There is in this context an ever smaller group of companies that combine scale and scope with others that target only the latter, such as the "gourmet specialty line." In the sector, the four largest companies audited by the "Alimarket" in 2011-2012 (Calvo, Frinsa, Garavilla and Jealsa Rianxeira) accounted for $59.23 \%$ of sales and $64.22 \%$ of the volume of processed fish. However, while the average price of their sales was between $€ 2,227.27$ and $€$ 2,000 / ton, that of smaller companies operating with specialties, the so-called "exquisitepreserves", like Conservas Ortiz and Luis Escuris Batalla, was between 3,571 and 4,533.33 € / ton.

In the current process, there are three other movements that draw disputes over the use of territory on multiple scales: (1) acquisitions of companies maintaining consolidated brands, such as Garavilla with Miau (of the Alfageme family), Massó (of the family of the same name), Cuca (of the Pita Hermanoscompany) and Conservas del Atlántico with the brand Curbera, which refers to one of the pioneers of preserves in Spain; (2) the gradual opening up of the companies' capital (investments of the Bolton GroupinCalvo); (3) externalization of parts of production and conflict

(14) Canning Industry, January-February 2012, p. 25-26. The publication is from ANFACO.

(15) The interviews with ANFACO and the companies confirmed the condition. 
in fisheries in territorial or international waters in the Indian and Pacific oceans and in factories built or acquired, for example by Jealsa, in Guatemala, and by Calvo, in El Salvador and Brazil.

\section{FINAL CONSIDERATIONS}

In the accelerated process of transformations in the relationships between companies, state, labor and natural dynamics, the analysis of the fishing industry as an economic activity that still has the priority raw material in the extraction of a living resource of great sensitivity and difficult measurement, can contribute to identifying and deciphering some of the ancient questions about life on the planet. With renewed concerns about the acceleration of innovation processes, there is an explanatory potential and possible intervention in the approach that considers the specificities of the SSF through the uses of the territory.

Industrial fish processing raises crucial issues for Geography, such as coping with the contradictory dynamics of Nature represented by the reproduction of different fish species with the social, economic, and political dynamics imposed in disputes between business, state, and workers' interests on vessels and in factories.

In the Spanish SSF, companies that combine different strategies that extrapolate the limits of the national territory are reproduced. Tensions lie in negotiations within the European Union and in the use of oceanic territories and those of other national states.

The companies' strategies include constant contributions of science, technology and information to guarantee new processes and products, as well as the control of material and non-material flows with the remote supervision of fisheries and international trade. These strategies aim to minimize the problems of access to regulated raw materials to maintain certain stocks, such as sardines and tuna, to flexibilize labor relations and sanitary standards related to the action of international and commercial competitors that tend to affirm their own brands. Hence the territorial significance of business strategies to insist on the status of Galicians with products with a designated origin and geographical indication that occur in the global system.

Can Spain, and especially Galicia, with its fishing companies, be a maritime power? Is this theme an economic and political discourse about territory and society? What are the strategies of these companies in other territories, especially in Latin America and Brazil, given the past of Spanish investments in different sectors? The trajectory of companies in territorial disputes is one of the ways to better understand these questions and explain the concreteness of the world.

\section{ACKNOWLEDGEMENT}

The text is part of postdoctoral research with a BEX / CAPES scholarship in the Department of Geography of the Universitat Autonoma de Barcelona, coordinated by Professor Antoni Tulla, of the activities of the research project "Fishing industry in the South of Brazil: the use of the territory by the fish canning and freezing companies" financed by the MCTI / CNPq / MEC / CAPES edict $\mathrm{n}^{\circ}$ 18/2012 and presented as communication at the VI Ibero-American Congress of Territorial and Environmental Studies.

\section{BIBLIOGRAPHIC REFERENCE}

ABELEDO, L. M. Género, trabajo y niveles de vida en la indústria conservera de Galicia: 1870-1970. Barcelona: Editorial Icária, 2010.

ALCUBILLA, P. Lineal de conservas de pescado: entre las grandes marcas y la MDD. Madrid: Alimarket-alimentácion, 2012. 
CARMONA BADIA, X. (coord.). Las famílias de La conserva: el sector de lãs conservas de pescados a traves de sus sagas familiares. Vigo: Diputacion de Pontevedra/ANFACO, 2011.

CARMONA BADIA, X. y NADAL OLLER, J. Galícia industrial (c. 1750-2005). A Cõruna: Fundácion Barrie, 2012.

BEIRAS, X.M (1972). O atraso econômico da Galiza. 3.ed. Santiago de Compostela; Laiovento, 1997.

DÍAZ DE RÁBAGO, J. La industria de la pesca em Galicia. Santiago: Fundación Pedro Barrié de La Maza, 1885.

FAO. Consecuencias del cambio climatico para la pesca y la acuicultura: visión de conjunto del estado de conecimientos cientificos . Roma, 2012.

FERREIRA PRIEGUE, E. O desenvolvimento da actividade pesqueira desde a alta idade media ó século XVII. In: FERNÁNDEZ CASANOVA, C. Historia da pesca en Galicia. Santiago: USC, 1998, p. 51-86.

GIRALDEZ RIVERO, J. Fuentes estadísticas y produccion pesquera em España (1880-1936): uma primeira aproximacion. Revista de Historia Económica, ano IX, n.3., 1991, p.p. 529.

GONÇALVES, R. A empresa transnacional. In: KUPFER, D. e HASENCLEVER, L. Economia industrial: fundamentos teóricos e práticos no Brasil. Rio de Janeiro: Campus, 2003, p.p. 389-411.

IGLESIAS, M. et al. As transformacións da economía clásica. In: PIÑEIRA MANTIÑAN, M.J. e SANTOS SOLLA, X.M. (coords.). Xeografía de Galicia. Vigo: Xerais, 2011, p.p. 279-358.

LAGO, Paulo Fernando. Renovacao de recursos aquaticos: o exemplo japones. Revista de Ciências Humanas. Florianopolis v. 1, n.2., 1982, p.p. 49-67.

LEFEBVRE, H. Les inégalités dans le MPE. In: De L'État 3: Le mode de production étatique. Paris: Union Générale D’Éditions, 1978, p.p. 269-372.

MARTINS, C.A.A. Indústria da pesca no Brasil:o uso do território por empresas de enlatamento de pescado. Tese (Doutorado)- Centro de Filosofia e Ciências Humanas, Universidade Federal de Santa Catarina, 2006. MÍGUEZ MACHO, A. Historia breve da Galícia. Madrid: Silex, 2011.

ORTEGA VALCARCEL, J. Cantabria (1886-1986): formación y desarrollo de una economía moderna. Santander: Camara de Comercio, industria y navegación, 1986.

PEREIRA, D. Foulas e ronseis. Santiago de Compostela: Positivas, 1998.

PEREIRA, D. (coord.). Os conquistadores modernos: movimento obreiro na Galicia de anteguerra. Vigo: Edición Nossa Terra, 1992.

ROBERTS, C. The unnatural history of the sea: the past and future of humanity and fishing. London: Octopus Publishing, 2007

ROSEMBERG, N. Por dentro da caixa-preta. Campinas: EDUNICAMP, 2006.

SANDRONI, P. (org.). Novo dicionário de Economia. $5^{\circ}$ edição. S.Paulo: Nova Cultural, 1994.

SAN MIGUEL, E.P. y GOMEZ BLANCO, A.G. Por todo los mares del mundo: lo prodigio de la pesca em Vigo. Vigo: Fundación Caixanova, 2009.

SANTOS CASTROVIEJO, I. Os séculos XVIII e XIX (ata 1870): protagonistas e transformacións. In: FERNÁNDEZ CASANOVA, C. Historia da pesca en Galicia. Santiago: USC, 1998, p.p. 87- 139.

SANTOS, M. A natureza do espaço: espaço e tempo, razão e emoção. S.Paulo: HUCITEC, 1996.

SANTOS, M. O período técnico-científico e os estudos geográficos. Revista do Departamento de Geografia. n. 4, 1985, p.p. 15-20.

SANTOS, M. Sociedade e espaço: a formação social como teoria e método. In: Espaço e sociedade. 2.ed. Petrópolis: Vozes, 1982, p. 9-27.

SANTOS, M. e SILVEIRA, M.L. Brasil: território e sociedade no século XXI. R.Janeiro: Record, 2001.

TAMANES, E. y RUEDA, A. Estructura económica de España. 25. ed. Madrid: Alianza,2008.

VELEDA DA SILVA, S.M. e MARTINS, C.A.A. O trabalho assalariado feminino nas fábrica de pescado na Galícia. Finisterra L1, 103, 2016, p.p. 25-43.

WALLERSTEIN, I. Mudando a geopolítica do sistema-mundo: 1945-2025. In: SADER, E. e SANTOS, T. (coords.). AAmérica Latina e os desafios da globalização. R.Janeiro: PUC-RJ/BoiTempo, 2009, p.p. 53-78. 